\title{
Investigating the Effects of Atmospheric Pressure Air DBD Plasma on Physio-Chemical and Microbial Parameters of Groundwater
}

\author{
Reema Shrestha1, Suman Prakash Pradhan', Rajesh Prakash Guragain1, \\ Deepak Prasad Subedi1, Bishnu Prasad Pandey ${ }^{2 *}$ \\ ${ }^{1}$ Department of Physics, Kathmandu University, Dhulikhel, Nepal \\ ${ }^{2}$ Department of Chemical Science and Engineering, Kathmandu University, Dhulikhel, Nepal \\ Email: ^bishnu@ku.edu.np
}

How to cite this paper: Shrestha, R., Pradhan, S.P., Guragain, R.P., Subedi, D.P. and Pandey, B.P. (2020) Investigating the Effects of Atmospheric Pressure Air DBD Plasma on Physio-Chemical and Microbial Parameters of Groundwater. Open Access Library Journal, 7: e6144.

https://doi.org/10.4236/oalib.1106144

Received: February 7, 2020

Accepted: March 24, 2020

Published: March 27, 2020

Copyright $\odot 2020$ by author(s) and Open Access Library Inc.

This work is licensed under the Creative Commons Attribution International License (CC BY 4.0).

http://creativecommons.org/licenses/by/4.0/

(c) $\underset{\mathrm{By}}{\text { (i) Open Access }}$

\begin{abstract}
Cold atmospheric pressure plasma generated at atmospheric air produces high energetic electrons, ions, UV radiations, reactive oxygen, and nitrogen species (RONS) which has a wide range of applications in biomedicine, agriculture, textiles, water treatment, etc. Recently, many researches have been carried out on ozonation through DBD (Dielectric barrier discharge) plasma in water treatment. However, direct plasma treatment on water hasn't been extensively studied yet. In this study, we examined the change in physical, chemical and biological parameters of groundwater by the means of direct DBD plasma activation. The significant reduction in the concentration of biological parameters such as total coliform and $E$. coli with increasing treatment time was found. Besides that, DBD plasma also lowered down the concentration of physical parameters such as $\mathrm{pH}$, turbidity, total suspended solids, total dissolved solids, and increased electrical conductivity and dissolved oxygen. In addition, the significant drop in the concentration of chemical parameters such as sodium, phosphorus, and calcium was found along with the reduction in heavy metals concentration such as iron, cadmium, lead, chromium, manganese, and zinc. However, the concentration of nitrite, nitrate, and sulfur augmented gradually. Our results revealed the great ability of direct plasma in water treatment.
\end{abstract}

\section{Subject Areas \\ Computational Chemistry}

\section{Keywords}

Plasma Treatment, RONS, Physio-Chemical, Microbial, Water 


\section{Introduction}

While access to safe drinking water is essential for the health and well-being of all living beings [1], most of the people are unable to access adequate and safe drinking water, especially in developing countries [2] [3]. Groundwater is water contained in an aquifer matrix located beneath the surface in the saturated zone [4] [5] and the quality of groundwater is interrelated with factors such as climate, slope, drainage conditions, water-rock interaction, and anthropogenic activities [6]. The dramatic shored up in water pollution especially due to the rapid population growth and unsustainable urbanization exacerbated the quality of water, which is the leading cause of humans to have dreadful health problems [7] [8] [9]. Many factors such as inter person transmission, food contamination, poor sanitation, and water contamination through fecal-oral route surge the waterborne infectious disease outbreaks [10] [11].

One of the contemporary researches in the field of quality of water is the treatment of water by cold plasma [12] [13] [14] [15]. Among the various methods adapted, dielectric barrier discharge (DBD) plasma has high efficiency in removing contamination [16]. In general, the cold plasma at atmospheric pressure in ambient air produces high energetic electrons, ions, reactive oxygen and nitrogen species (RONS), and ultraviolet radiation which when treated with water changes its parameters out of which, ozone is the stable, long-lived species [17] whereas some of the hydroxyl ions and nitrogen species are short-lived species [18] [19] [20]. Various researches have been carried out on water purification through ozone produced by DBD plasma [21] [22], however, direct plasma discharge treatment in water has yet not been studied in detail. In this method, not only ozone but other short-lived reactive species get to interact with water [20]. The reaction mechanism during the plasma discharge is as follows:

$$
\begin{gathered}
\mathrm{O}_{2}+\mathrm{e}^{-} \rightarrow \mathrm{O}+\mathrm{O}+\mathrm{e}^{-1} \\
\mathrm{O}_{2}+\mathrm{O} \rightarrow \mathrm{O}_{3} \\
3 \mathrm{O}_{3}+\mathrm{H}_{2} \mathrm{O} \rightarrow 2 \mathrm{OH}^{\star}+4 \mathrm{O}_{2} \\
\mathrm{e}^{-}+\mathrm{H}_{2} \mathrm{O} \rightarrow \mathrm{OH}^{*}+\mathrm{H}^{*}+\mathrm{e}^{-1}
\end{gathered}
$$

The main objective of this study was to identify the ability of direct plasmatreated discharge treatment in enhancing the water quality on the basis of the research question; what are the effects of direct plasma-treated discharge in changing the groundwater quality parameters?

\section{Experimental Procedure}

\subsection{Experimental Setup}

In the experimental setup for plasma treatment, the reactor system was covered by a transparent glass cylinder and consists of two electrodes of dimension $(5.10 \mathrm{~cm}$ diameter and $1 \mathrm{~cm}$ thickness) made up of brass inside. A petri dish of borosilicate glass acts as a dielectric barrier, with water of volume $40 \mathrm{ml}$ was kept between the electrodes. The distance between the upper electrode and 
surface of the water is $1.8 \mathrm{~cm}$ and the distance between two electrodes is 2.2 $\mathrm{cm}$. A small hole at the top is made to allow external airflow. The two terminals of the high voltage probe are connected to the upper and lower electrodes of the plasma reactor.

The current probe is attached across the shunt resistor which is then fed into the oscilloscope (Tektronics TDS 2002 digital oscilloscope) for current measurement. A high voltage of $13.71 \mathrm{KV}$ at line frequency of $50 \mathrm{~Hz}$ was applied. The power consumed by the discharge was 32.96 Watt (Figure 1).

\subsection{Sample Collection}

The water sample was taken from groundwater well of one residential house (common well) of Panauti municipality of Kavreplanchowk District of Bagmati

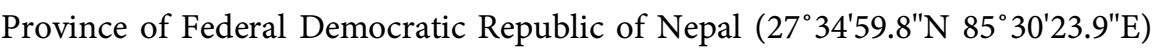
in June 2019. The samples were stored at $4^{\circ} \mathrm{C}$ in the refrigerator.

\subsection{Analytical Methods}

The standard methods were used to determine physiochemical and biological parameters [23]. Physical parameters; $\mathrm{pH}$, electrical conductivity (EC) and dissolved oxygen (DO) were measured using standard multi-probe (HANNA edge with HI764080 and HI11310 probe) whereas the turbidity was determined by turbidity meter (HANNA HI88703-Turbidimeter). The total dissolved solids (TDS), and total suspended solids (TSS) were analyzed by the gravimetric method. Biological parameters; total coliform and $E$. coli were determined by the membrane filter technique.

The chemical parameters; nitrate $\left(\mathrm{NO}_{3}^{-}\right)$, nitrite $\left(\mathrm{NO}_{2}^{-}\right)$, total iron $(\mathrm{Fe})$, chromium $(\mathrm{Cr})$, manganese $(\mathrm{Mn})$, sulfur $(\mathrm{S})$ and phosphorus $(\mathrm{P})$ determination were carried out by UV-Spectrophotometer (Shimadzu UV-1800). Whereas sodium $(\mathrm{Na})$, lead $(\mathrm{Pb})$, Cadmium $(\mathrm{Cd})$, calcium $(\mathrm{Ca})$, and zinc $(\mathrm{Zn})$ were determined by atomic absorption spectrometry (SavantAA, GBS).

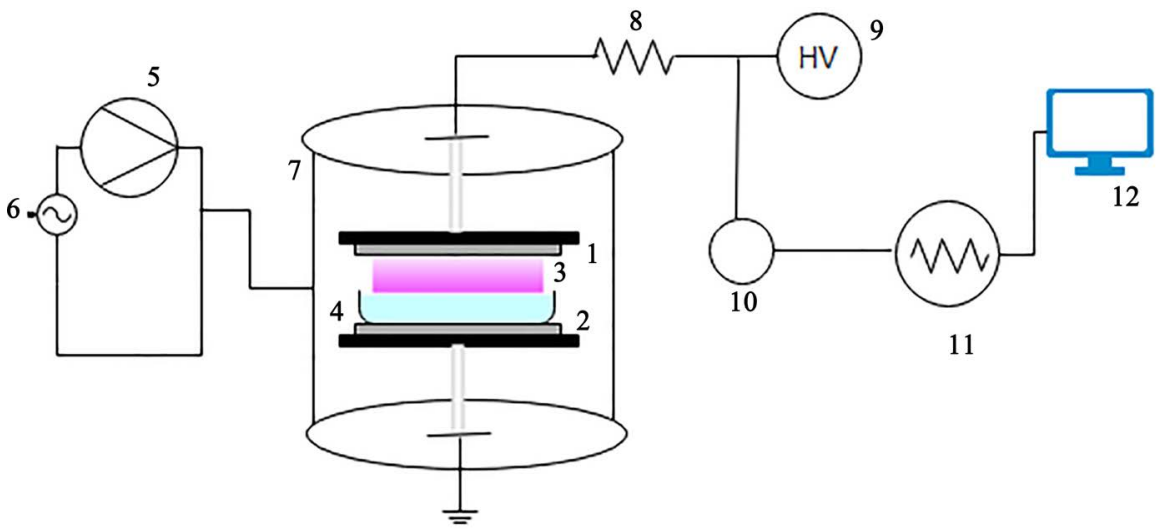

Figure 1. Schematic diagram of the experimental setup: Electrodes $(1,2)$, Plasma discharge (3), Petri dish with sample water (4), Air pump (5), Power supply (6), Transparent cylinder (7), Ballast resistor (8), High Voltage supply (9), High Voltage Probe (10), Shunt resistor (11), Personal Computer (12) 


\subsection{Statistical Analysis}

All the experiments were carried out triplicate and data were presented in mean \pm SD. Pearson's correlation analysis was done for physio-chemical parameters data analysis with $95 \%$ confidence interval.

\section{Results and Discussions}

\subsection{Physical Parameters}

$\mathrm{pH}$ is responsible for the corrosivity of water [24] and the low $\mathrm{pH}$ of water might cause severe ailment like gastrointestinal disorder [25]. Our results revealed the gradual declination of $\mathrm{pH}$ with an increase in plasma treatment time (Table 1). The responsible factors for the decrease in $\mathrm{pH}$ might be several RONS species which are produced during plasma treatment on water and plasma acids [26] [27]. Electrical conductivity is one of the indicators of dissolved inorganic ions in water [28]. The electrical conductivity (EC) and dissolved oxygen (DO) in plasma-treated waters were increased linearly (Table 1 ) and this result is consonant with the previous works [12] [29] [30]. Due to the presence of particulates such as clay, silt, organic matter, algae, and other microorganisms water loses its transparency and known for turbid [31] which can cause severe health disorder [25]. Our results revealed a decrease in turbidity with the increase in plasma treatment time which is related to the decrease in total dissolved and suspended solids on the treated water (Table 1). Total dissolved solids (TDS) is the sum of inorganic salts and small amounts of organic matter present in water which usually consists of sulfates, calcium, magnesium, nitrate, nitrites, etc. [32]. Plasma treatment shows significant decrease of TDS in water (Table 1). The total suspended solids (TSS) are the dry weight of the non-dissolving particles in water. Plasma treatment shows significant changes with decrease in TSS as well; which is similar to the results of the previous investigators [12]. The overall results of physical parameters showed a significant negative correlation with treatment time $(\mathrm{p}<0.05)$ i.e. the concentration of parameters decreased significantly with an increase in plasma treatment time whereas DO and EC showed positive correlation with the treatment time $(\mathrm{p}<0.05)$.

\subsection{Biological Parameters}

Reactive species such as $\mathrm{OH}, \mathrm{H}_{2} \mathrm{O}_{2}, \mathrm{NO}_{3}^{-}$, and $\mathrm{O}_{3}$ in the liquid have potent effects on microorganisms [33] [34]. E. coli and coliform bacteria are the fecal pollution indicators that are used to evaluate the health of aquatic ecosystems and the potential for health effects among individuals within those environments [35]. Safe drinking water requires the stability of the microbial community to minimize the release of pathogen [36] and environmental conditions that favor an increased load of pathogens in water also are crucial factors contributing to outbreaks of waterborne diseases [37] [38]. Our results revealed a significant decrease in the colony forming unit (CFU) per $100 \mathrm{~mL}$ sample for $E$. coli as well as total coliform with the increase in plasma treatment time (Table 1). Since, the 
Table 1. Results on physical and biological parameters.

\begin{tabular}{|c|c|c|c|c|c|}
\hline \multicolumn{2}{|r|}{ Parameters } & \multicolumn{4}{|c|}{ Treatment Time } \\
\hline & & Untreated & 5 minutes & 10 minutes & 15 minutes \\
\hline \multirow[t]{6}{*}{ Physical } & $\mathrm{pH}$ & $8.90 \pm 0.00$ & $8.80 \pm 0.00$ & $8.70 \pm 0.00$ & $8.60 \pm 0.00$ \\
\hline & Turbidity (NTU) & $1.40 \pm 0.00$ & $1.30 \pm 0.00$ & $0.85 \pm 0.00$ & $0.70 \pm 0.00$ \\
\hline & Dissolved Oxygen (mg/L) & $6.50 \pm 0.00$ & $6.61 \pm 0.00$ & $6.70 \pm 0.02$ & $6.96 \pm 0.02$ \\
\hline & Conductivity $(\mu \mathrm{S} / \mathrm{cm})$ & $262.00 \pm 0.00$ & $264.00 \pm 0.00$ & $266.00 \pm 0.00$ & $268.00 \pm 0.00$ \\
\hline & Total Dissolved Solid (mg/L) & $150.00 \pm 0.06$ & $50.00 \pm 0.00$ & $25.00 \pm 0.00$ & $0.00 \pm 0.00$ \\
\hline & Total Suspended Solid (mg/L) & $75.00 \pm 0.05$ & $50.00 \pm 0.00$ & $25.00 \pm 0.00$ & $0.00 \pm 0.00$ \\
\hline \multirow[t]{2}{*}{ Biological } & Escherichia coli (CFU/100 mL) & $>100$ & $>50$ & 0 & 0 \\
\hline & Total Coliform (CFU/100 mL) & $>100$ & $>50$ & 0 & 0 \\
\hline
\end{tabular}

major factor for the increase in bacterial inactivation might be the increase in the applied voltage which increases the production of reactive species; by means of electroporation, cell membrane permeability increases and the reactive species kills the microorganism by deactivating the cell [15]. This significance positive effects of plasma treatment on controlling $E$. coli and total coliform are advantageous in water treatment.

\subsection{Chemical Parameters}

Calcium is abundant in drinking water; mainly helps in maintaining bones and essential for the functioning of muscles and nervous system [39] and lack of this ion causes cardiovascular disease [40]. However, a high level of calcium consumption leads to nausea, vomiting, weakness, and muscle cramp and bone pain [41] [42]. The hexavalent chromium is one of the dangerous heavy metals found in well water [43]. The chromium reacts with oxygen at room temperature to form oxides and also with other reactive species like hydroxides and plays an important role in the maintenance of normal glucose metabolism and acts as a cofactor for insulin [44]. Manganese is a pernicious heavy metal found in well water; although, a high level of manganese causes nervous system disorder, sperm damage, impairments fertility, nephritis, and nephrolithiasis [45] [46] [47]. Although naturally present phosphorus in water is not harmful to humans, high concentration can cause dreadful diseases such as diarrhea, hardening of organs and soft tissues [48]. The fluctuating trend of phosphorus in plasma treated water is pronounced in the previous works [29]. Our results revealed the decrease in calcium, chromium, manganese, and phosphorus concentration with an increase in plasma treatment time (Figures $2(a)-(d)$ ).

The excessive intake of nitrate with drinking water causes thyroid, colorectal cancer, breast cancer, methemoglobinemia [45] [49]. Since, plasma discharge produces reactive nitrogen species like $\mathrm{NO}_{2}^{-}$and $\mathrm{NO}_{3}^{-}$, which results in the increase of concentration of nitrate and nitrite in water with the increase in treatment time (Figure 3(a) \& Figure 3(b)). These results are comparative with the 


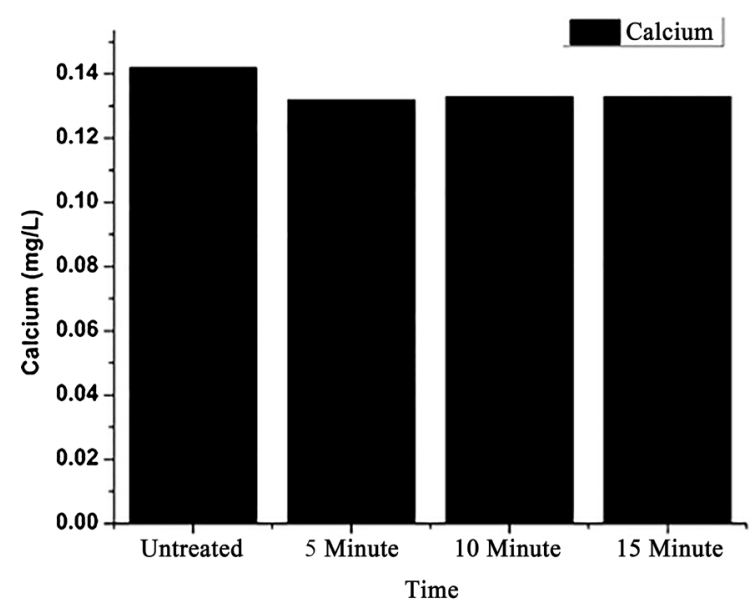

(a) Calcium

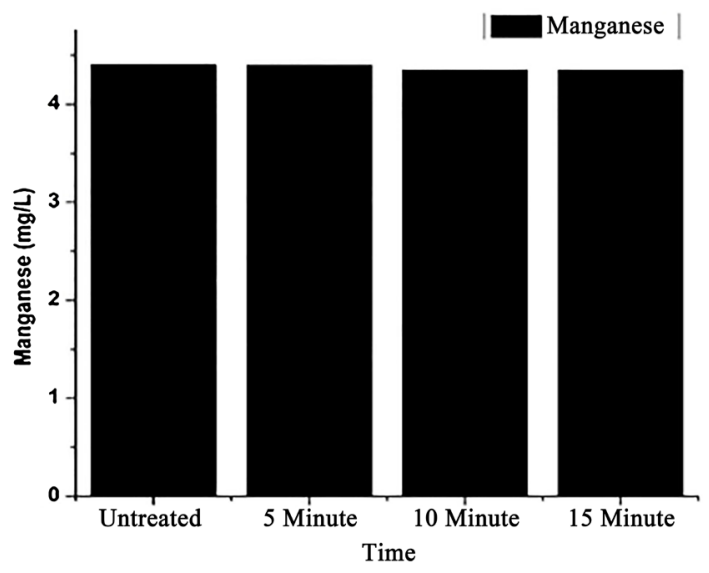

(c) Manganese

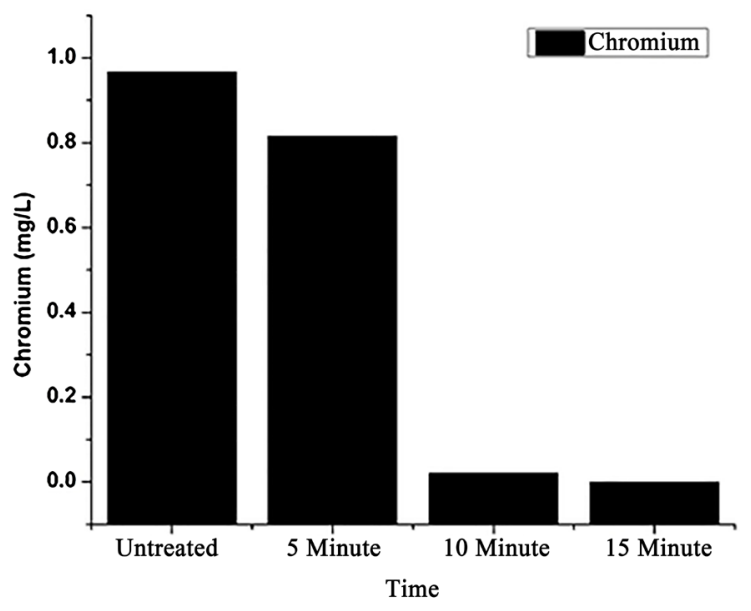

(b) Chromium

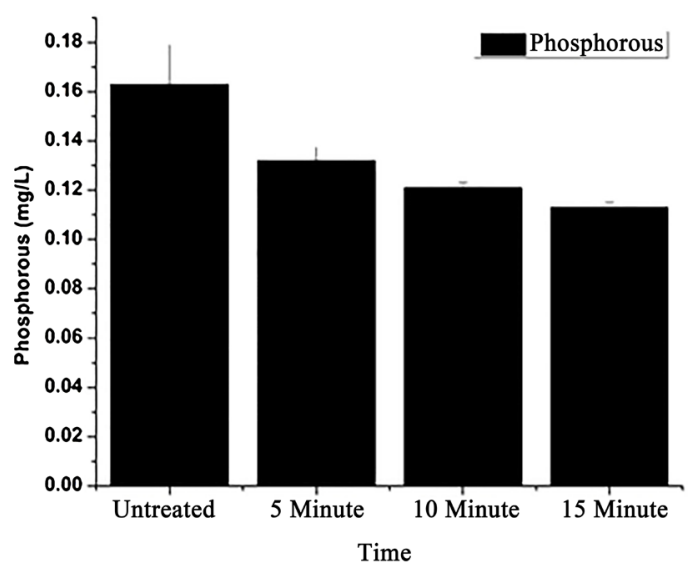

(d) Phosphorous

Figure 2. Results on calcium, chromium, manganese and phosphorus.

results from previous investigators [12] [14]. Very low sodium on diet is recommended by the Environmental Protection Agency (EPA); the higher concentration of sodium intake could cause severe health impacts on living beings [50]. Our results showed the decreasing trend of sodium with increasing treatment times (Figure 3(c)). Sulfur doesn't create any great health hazards but exposure to excessive concentration might create a temporary laxative effect such as irritation to the skin, eye, and respiratory problems [51] [52] [53]. The concentration of sulfate ion in control and plasma-treated samples shows the increasing trend (Figure 3(d)), which is a disadvantage of the plasma treatment.

Iron is the heavy metals found in drinking water which is generally good for health. However, the large concentration of iron in water is not suitable; which causes hemochromatosis, leading to effects on the liver, pancreases etc. [46]. The elevated level of iron imparts smell, taste, and stain on clothes [54]. In our result, the concentrations of iron in the control sample and plasma-treated water are varying in degree with the astonishing decrement (Figure 4(b)). The decreasing trend for iron concentration could be explained by the fact that iron reacts with ozone and hydroxides to form iron oxides and hydroxides which get precipitated 


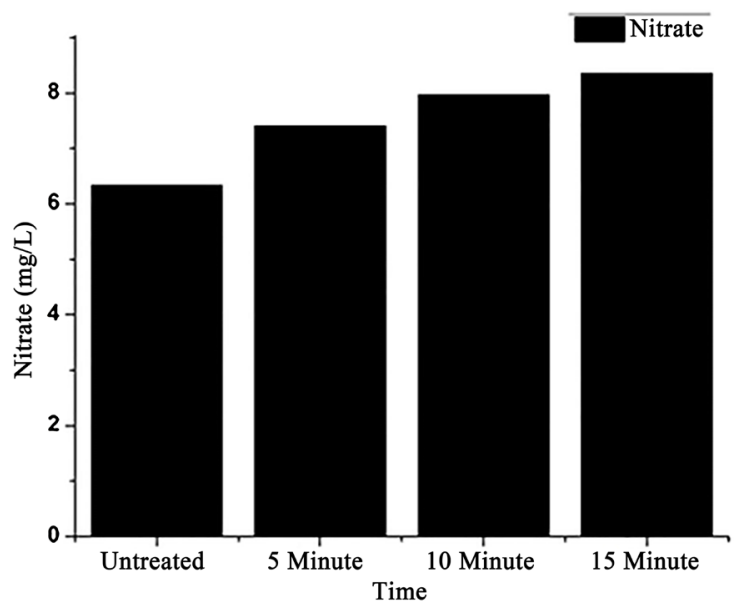

(a) Nitrate

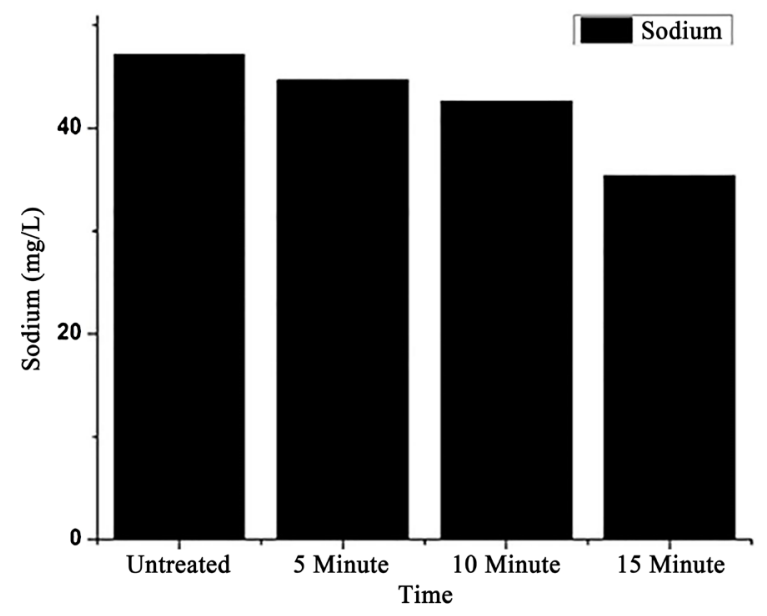

(c) Sodium

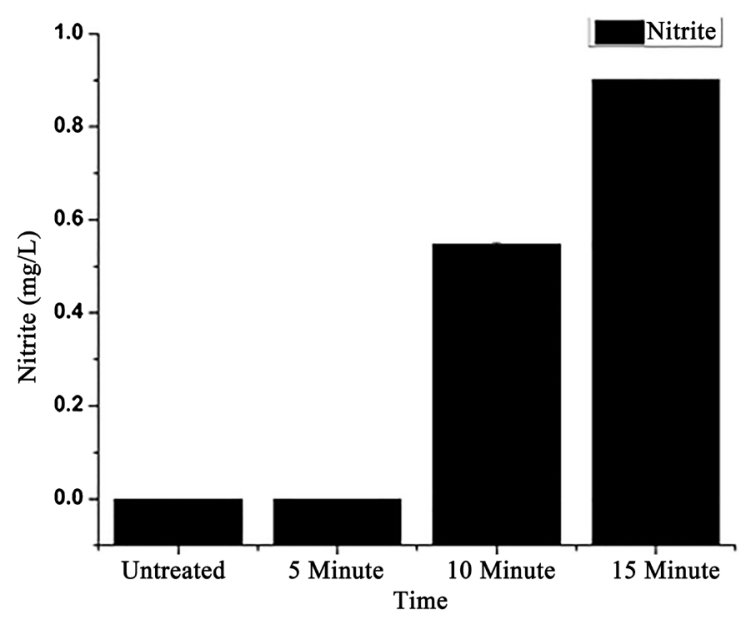

(b) Nitrite

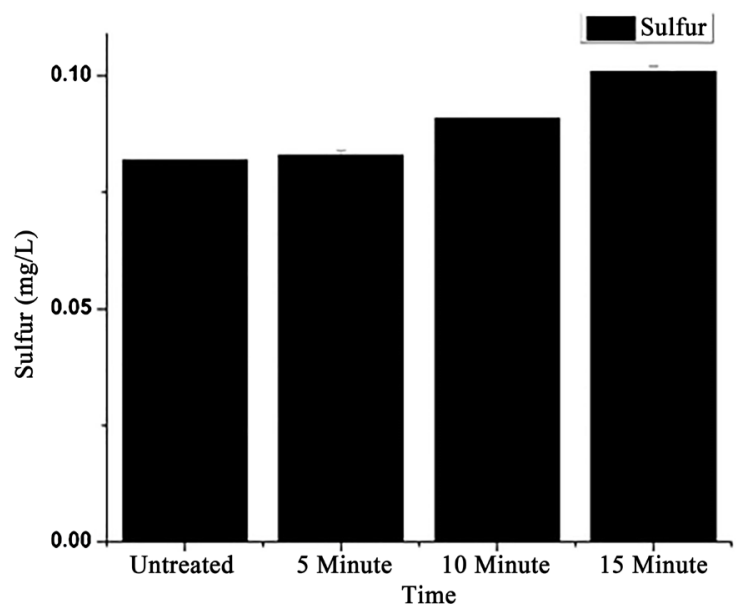

(d) Sulfur

Figure 3. Results on nitrate, nitrite, sodium and sulfur.

and settles at the bottom of the water [47]. Cadmium is a significant contaminant of water with high toxicity due to its easy solubility [55]. Despite low abundance in nature cadmium poses an increasing environmental and health risk with profound biological effects on human beings such as dysfunction of renal and lung [56]. Lead causes damage to the central nervous system [57] and also damage to the kidney, liver, reproductive system, and basic cellular processes [58]. Most zinc is introduced into water by artificially with increased anthropogenic activities and an excess amount of zinc in drinking water causes nausea and vomiting [59]. Our results showed the exceptional decrease in heavy metal content of water with the plasma treatment (Figures 4(a)-(d)). The overall results showed the significant negative correlation between the concentration examined chemical parameters and plasma treatment time $(\mathrm{p}<0.05)$ except the significant positive correlation for nitrate, nitrite and sulfur $(\mathrm{p}<0.05)$.

\section{Conclusion}

From this study, we can conclude that the direct plasma treatment in water has 


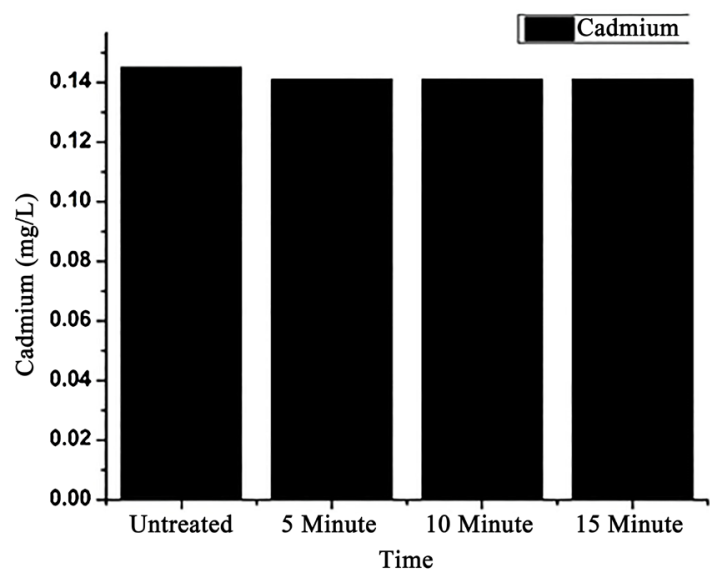

(a) Cadmium

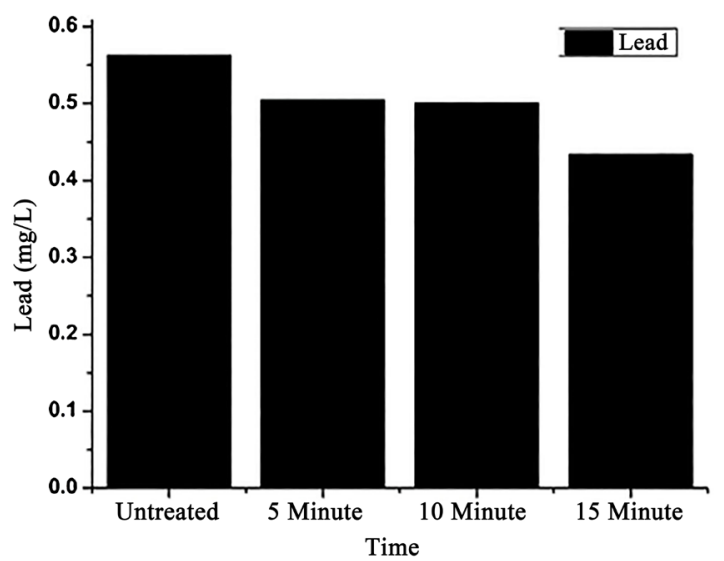

(c) Lead

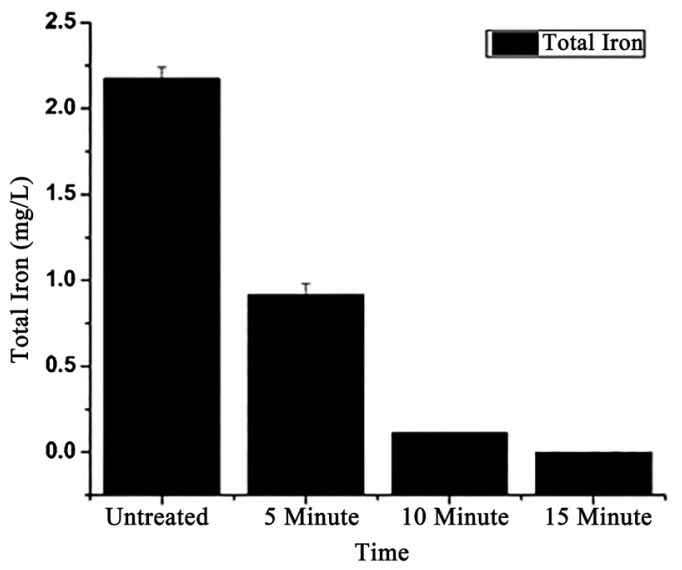

(b) Total Iron

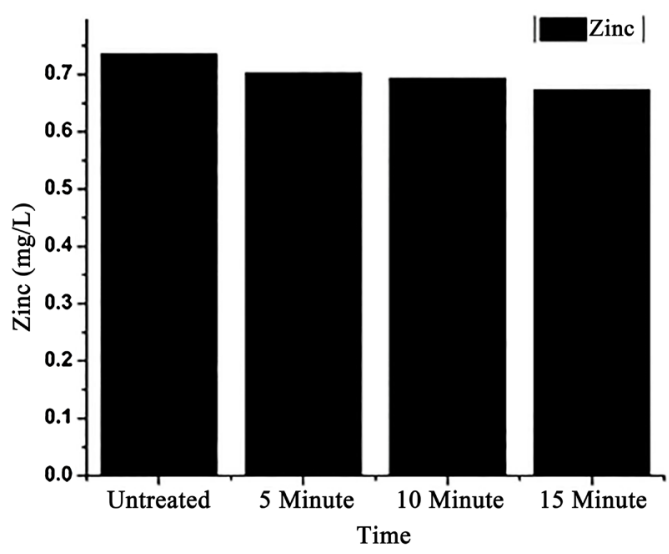

(d) Zinc

Figure 4. Results on cadmium, total iron, lead and zinc.

great significance in water quality enhancement. This study shows the potential of direct plasma treatment in the water for the disinfection of bacteria in the water and significant reduction of heavy metals content such as concentration of chromium, manganese, cadmium, iron, lead, and zinc. The overall result gave us the plethora of scientific evidence that the treatment of water with the direct atmospheric air pressure DBD plasma is beneficial for the treatment of water for different physical, chemical, and biological parameters whereas for some chemical parameters, this treatment is counterproductive. Ten minutes of plasma treatment are the best in augmenting overall parameters of groundwater. Moreover, the effects of plasma treatment on wastewater can be studied in future that would aid in the purification of water targeting a wider range of people.

\section{Acknowledgements}

We would like to thank Aquatic Ecology Center (AEC), Kathmandu University for AAS facility.

\section{Author's Contribution}

DPS, RS, RPG, SPP and BPP conceptualized and performed preliminary works. 
RS and SPP did the laboratory works, data generation, analysis and verification. RS, SPP, BPP, DPS wrote, edited and reviewed the manuscript.

\section{Conflicts of Interest}

The authors declare no conflicts of interest regarding the publication of this paper.

\section{References}

[1] Khan, S., Shahnaz, M., Jehan, N., Rehman, S., Shah, M.T. and Din, I. (2013) Drinking Water Quality and Human Health Risk in Charsadda District, Pakistan. Journal of Cleaner Production, 60, 93-101. https://doi.org/10.1016/j.jclepro.2012.02.016

[2] Shrestha, A., Sharma, S., Gerold, J., Erismann, S., Sagar, S., Koju, R., Schindler, C., Odermatt, P., Utzinger, J. and Cissé, G. (2017) Water Quality, Sanitation, and Hygiene Conditions in Schools and Households in Dolakha and Ramechhap Districts, Nepal: Results from a Cross-Sectional Survey. International Journal of Environmental Research and Public Health, 14, 89. https://doi.org/10.3390/ijerph14010089

[3] Pant, B.R. (2011) Ground Water Quality in the Kathmandu Valley of Nepal. Environmental Monitoring and Assessment, 178, 477-485.

https://doi.org/10.1007/s10661-010-1706-y

[4] Sharp, K.A. (2001) Water: Structure and Properties. https://doi.org/10.1038/npg.els.0003116

[5] Siebert, S., Burke, J., Faures, JM., Frenken, K., Hoogeveen, J., Döll, P. and Portmann, F.T. (2010) Groundwater Use for Irrigation: A Global Inventory. Hydrology and Earth System Sciences, 14, 1863-1880. https://doi.org/10.5194/hess-14-1863-2010

[6] Rao, N.S. (2006) Seasonal Variation of Groundwater Quality in a Part of Guntur District, Andhra Pradesh, India. Environmental Geology, 49, 413-429. https://doi.org/10.1007/s00254-005-0089-9

[7] Pink, D.H. (2006) Investing in Tomorrow's Liquid Gold. Yahoo.

[8] Neiderud, C.J. (2015) How Urbanization Affects the Epidemiology of Emerging Infectious Diseases. Infection Ecology \& Epidemiology, 5, 27-60. https://doi.org/10.3402/iee.v5.27060

[9] Kambole, M.S. (2003) Managing the Water Quality of the Kafue River. Physics and Chemistry of the Earth, Parts A/B/C, 28, 1105-1109.

https://doi.org/10.1016/j.pce.2003.08.031

[10] Grandesso, F., Allan, M., Jean-Simon, P.S., Boncy, J., Blake, A., Pierre, R., Alberti, K.P., Munger, A., Elder, G., Olson, D. and Porten, K. (2014) Risk Factors for Cholera Transmission in Haiti during Inter-Peak Periods: Insights to Improve Current Control Strategies from Two Case-Control Studies. Epidemiology \& Infection, 142 1625-1635. https://doi.org/10.1017/S0950268813002562

[11] Ashbolt, N.J. (2015) Microbial Contamination of Drinking Water and Human Health from Community Water Systems. Current Environmental Health Reports, 2, 95-106. https://doi.org/10.1007/s40572-014-0037-5

[12] Bhatta, R., Kayastha, R., Subedi, D.P. and Joshi, R. (2015) Treatment of Wastewater by Ozone Produced in Dielectric Barrier Discharge. Journal of Chemistry, 2015, Article ID: 648162. https://doi.org/10.1155/2015/648162

[13] Quyen, N., Traikool, T., Nitisoravut, R. and Onjun, T. (2017) Improvement of Wa- 
ter Quality Using Dielectric Barrier Discharge Plasma. Journal of Physics. Conference Series, 860, Article ID: 012031. https://doi.org/10.1088/1742-6596/860/1/012031

[14] Nguyen, D.V., Ho, P.Q., Pham, T.V., Nguyen, T.V. and Kim, L. (2018) Treatment of Surface Water Using Cold Plasma for Domestic Water Supply. Environmental Engineering Research, 24, 412-417. https://doi.org/10.4491/eer.2018.215

[15] Desmiarti, R., Hazmi, A. and Trianda, Y. (2015) Fecal Coliforms and Total Coliforms Removal in Water Using Radio-Frequency (RF) Plasma System. Modern Applied Science, 9, 80-85. https://doi.org/10.5539/mas.v9n7p80

[16] An, H.T.Q., Huu, T.P., Le Van, T., Cormier, J.M. and Khacef, A. (2011) Application of Atmospheric Non Thermal Plasma-Catalysis Hybrid System for Air Pollution Control: Toluene Removal. Catalysis Today, 176, 474-477. https://doi.org/10.1016/j.cattod.2010.10.005

[17] Harling, A.M., Glover, D.J., Whitehead, J.C. and Zhang, K. (2009) The Role of Ozone in the Plasma-Catalytic Destruction of Environmental Pollutants. Applied Catalysis B: Environmental, 90, 157-161. https://doi.org/10.1016/j.apcatb.2009.03.005

[18] Fridman, A., Yang, Y. and Cho, Y.I. (2012) Plasma Discharge in Liquid: Water Treatment and Applications. CRC Press, London.

[19] Kanazawa, S., Kawano, H., Watanabe, S., Furuki, T., Akamine, S., Ichiki, R., Ohkubo, T., Kocik, M. and Mizeraczyk, J. (2011) Observation of OH Radicals Produced by Pulsed Discharges on the Surface of a Liquid. Plasma Sources Science and Technology, 20, Article ID: 034010. https://doi.org/10.1088/0963-0252/20/3/034010

[20] Zhang, Z., Jie, S., Cheng, C., Zimu, X. and Weidong, X. (2018) Generation of Reactive Species in Atmospheric Pressure Dielectric Barrier Discharge with Liquid Water. Plasma Science and Technology, 20, Article ID: 044009. https://doi.org/10.1088/2058-6272/aaa437

[21] Bartis, E., Knoll, A., Luan, P., Seog, J. and Oehrlein, G. (2016) On the Interaction of Cold Atmospheric Pressure Plasma with Surfaces of Bio-Molecules and Model Polymers. Plasma Chemistry and Plasma Processing, 36, 121-149. https://doi.org/10.1007/s11090-015-9673-2

[22] Van Deynse, A., De Geyter, N., Leys, C. and Morent, R. (2014) Influence of Water Vapor Addition on the Surface Modification of Polyethylene in an Argon Dielectric Barrier Discharge. Plasma Processes and Polymers, 11, 117-125. https://doi.org/10.1002/ppap.201300088

[23] APHA (2012) Standard Methods for the Examination of Water and Wastewater. American Public Health Association, Washington DC.

[24] Shah, M., Ara, J., Muhammad, S., Khan, S. and Tariq, S. (2012) Health Risk Assessment via Surface Water and Sub-Surface Water Consumption in the Mafic and Ultramafic Terrain, Mohmand Agency, Northern Pakistan. Journal of Geochemical Exploration, 118, 60-67. https://doi.org/10.1016/j.gexplo.2012.04.008

[25] WHO (2011) Guidelines for Drinking-Water Quality. 4th Edition, World Health Organization, Geneva.

[26] Shainsky, N., Dobrynin, D., Ercan, U., Joshi, S.G., Ji, H., Brooks, A., Fridman, G., Cho, Y., Fridman, A. and Friedman, G. (2012) Plasma Acid: Water Treated by Dielectric Barrier Discharge. Plasma Processes and Polymers, 9, 1-6. https://doi.org/10.1002/ppap.201100084

[27] Bian, W., Zhou, M. and Lei, L. (2007) Formations of Active Species and by-Products in Water by Pulsed High-Voltage Discharge. Plasma Chemistry and Plasma Processing, 
27, 337-348. https://doi.org/10.1007/s11090-007-9066-2

[28] Mahato, S., Mahato, A., Karna, P.K. and Balmiki, N. (2018) Investigating Aquifer Contamination and Groundwater Quality in Eastern Terai Region of Nepal. BMC Research Notes, 11, 321. https://doi.org/10.1186/s13104-018-3445-Z

[29] Judée, F., Simon, S., Bailly, C. and Dufour, T. (2018) Plasma-Activation of Tap Water Using DBD for Agronomy Applications: Identification and Quantification of Long Lifetime Chemical Species and Production/Consumption Mechanisms. Water Research, 133, 47-59. https://doi.org/10.1016/j.watres.2017.12.035

[30] Subedi, D.P., Tyata, R., Khadgi, A. and Wong, C. (2009) Treatment of Water by Dielectric Barrier Discharge. Journal of Science and Technology in the Tropics, 5 , 117-123.

[31] Patel, H. and Vashi, R. (2015) Characterization and Column Adsorptive Treatment for COD and Color Removal Using Activated Neem Leaf Powder from Textile Wastewater. Journal of Urban and Environmental Engineering, 9, 45-53. https://doi.org/10.4090/juee.2015.v9n1.045053

[32] Fawell, J., Lund, U. and Mintz, B. (2003) Total Dissolved Solids in Drinking-Water. Background Document for Development of WHO Guidelines for Drinking-Water Quality. World Health Organization, Geneva.

[33] Lukes, P., Brisset, J.L. and Locke, B.R. (2012) Biological Effects of Electrical Discharge Plasma in Water and in Gas-Liquid Environments. Plasma Chemistry and Catalysis in Gases and Liquids, 1, 309-352. https://doi.org/10.1002/9783527649525.ch8

[34] Wu, H., Sun, P., Feng, H., Zhou, H., Wang, R., Liang, Y., Lu, J., Zhu, W., Zhang, J. and Fang, J. (2012) Reactive Oxygen Species in a Non-Thermal Plasma Microjet and Water System: Generation, Conversion, and Contributions to Bacteria Inactivation-An Analysis by Electron Spin Resonance Spectroscopy. Plasma Processes and Polymers, 9, 417-424. https://doi.org/10.1002/ppap.201100065

[35] McLellan, S.L., Daniels, A.D. and Salmore, A.K. (2001) Clonal Populations of Thermotolerant Enterobacteriaceae in Recreational Water and Their Potential Interference with Fecal Escherichia coli Counts. Applied Environmental Microbiology, 67, 4934-4938. https://doi.org/10.1128/AEM.67.10.4934-4938.2001

[36] Uprety, S., Hong, P.Y., Sadik, N., Dangol, B., Adhikari, R., Jutla, A., Shisler, J.L., Degnan, P. and Nguyen, T.H. (2017) The Effect of the 2015 Earthquake on the Bacterial Community Compositions in Water in Nepal. Frontiers in Microbiology, 8 , 2380. https://doi.org/10.3389/fmicb.2017.02380

[37] Lobitz, B., Beck, L., Huq, A., Wood, B., Fuchs, G., Faruque, A.S. and Colwell, R. (2000) Climate and Infectious Disease: Use of Remote Sensing for Detection of Vibrio Cholerae by Indirect Measurement. Proceedings of the National Academy of Sciences, 97, 1438-1443. https://doi.org/10.1073/pnas.97.4.1438

[38] Jutla, A., Whitcombe, E., Hasan, N., Haley, B., Akanda, A., Huq, A., Alam, M., Sack, R.B. and Colwell, R. (2013) Environmental Factors Influencing Epidemic Cholera. The American Journal of Tropical Medicine and Hygiene, 89, 597-607. https://doi.org/10.4269/ajtmh.12-0721

[39] Mohanty, B.P., Sankar, T.V., Ganguly, S., Mahanty, A., Anandan, R., Chakraborty, K., Paul, B.N., Sarma, D., Dayal, J.S., Mathew, S. and Asha, K.K. (2016) Micronutrient Composition of 35 Food Fishes from India and Their Significance in Human Nutrition. Biological Trace Element Research, 174, 448-458. https://doi.org/10.1007/s12011-016-0714-3

[40] Radfard, M., Yunesian, M., Nabizadeh, R., Biglari, H., Nazmara, S., Hadi, M., You- 
sefi, N., Yousefi, M., Abbasnia, A. and Mahvi, A.H. (2019) Drinking Water Quality and Arsenic Health Risk Assessment in Sistan and Baluchestan, Southeastern Province, Iran. Human and Ecological Risk Assessment. An International Journal, 25, 949-965. https://doi.org/10.1080/10807039.2018.1458210

[41] Ferguson, S.J. (2017) What Is the Effect of Calcium, Vitamin D and Phosphorus Intake on the Occurrence of Stress Fractures in Male and Female Cross Country Collegiate Athletes? Lamar University, Beaumont, TX.

[42] N.I.H. Calcium. National Institutes of Health. https://ods.od.nih.gov/factsheets/Calcium-HealthProfessional/

[43] WHO (2011) Guidelines for Drinking-Water Quality. WHO Chronicle, 38, 104-108.

[44] Zinicovscaia, I., Gundorina, S., Vergel, K., Grozdov, D., Ciocarlan, A., Aricu, A., Dragalin, I. and Ciocarlan, N. (2020) Elemental Analysis of Lamiaceae Medicinal and Aromatic Plants Growing in the Republic of Moldova Using Neutron Activation Analysis. Phytochemistry Letters, 35, 119-127.

https://doi.org/10.1016/j.phytol.2019.10.009

[45] Ward, M., Jones, R., Brender, J., de Kok, T., Weyer, P., Nolan, B., Villanueva, C. and van Breda, S. (2018) Drinking Water Nitrate and Human Health: An Updated Review. International Journal of Environmental Research and Public Health, 15, 1557. https://doi.org/10.3390/ijerph15071557

[46] WHO (1993) Guidelines for Drinking-Water Quality. World Health Organization.

[47] El Araby, R., Hawash, S. and El Diwani, G. (2009) Treatment of Iron and Manganese in Simulated Groundwater via Ozone Technology. Desalination, 249, 1345-1349. https://doi.org/10.1016/j.desal.2009.05.006

[48] Anderson, J.J. (1996) Calcium, Phosphorus and Human Bone Development. The Journal of Nutrition, 126, 1153S-1158S. https://doi.org/10.1093/jn/126.suppl_4.1153S

[49] Yang, C.Y., Chang, C.C., Tsai, S.S. and Chiu, H.F. (2006) Calcium and Magnesium in Drinking Water and Risk of Death from Acute Myocardial Infarction in Taiwan. Environmental Research, 101, 407-411. https://doi.org/10.1016/j.envres.2005.12.019

[50] USEP (2003) Drinking Water Advisory: Consumer Acceptability Advice and Health Effects Analysis on Sodium EPA 822-R-03-006. US Environmental Protection Agency Office of Water (4304T), Health and Ecological Criteria Division, Washington DC.

[51] Hedley, A.J., Wong, C.M., Thach, T.Q., Ma, S., Lam, T.H. and Anderson, H.R. (2002) Cardiorespiratory and All-Cause Mortality after Restrictions on Sulphur Content of Fuel in Hong Kong: An Intervention Study. The Lancet, 360, 1646-1652. https://doi.org/10.1016/S0140-6736(02)11612-6

[52] Geravandi, S., Goudarzi, G., Babaei, A.A., Takdastan, A., Mohammadi, M.J., Niri, M.V., Salmanzadeh, S. and Shirbeigi, E. (2015) Health Endpoint Attributed to Sulfur Dioxide Air Pollutants. Jundishapur Journal of Health Sciences, 7, e29377. https://doi.org/10.5812/jihs.29377v2

[53] Hewlings, S. and Kalman, D. (2019) Sulfur in Human Health. EC Nutrition, 14, 785-791.

[54] WHO (2011) Iron in Drinking-Water: Background Document for Development of WHO Guidelines for Drinking-Water Quality. World Health Organization, Geneva.

[55] Hanif, N., Eqani, S.A., Ali, S.M., Cincinelli, A., Ali, N., Katsoyiannis, I.A., Tanveer, Z.I. and Bokhari, H. (2016) Geo-Accumulation and Enrichment of Trace Metals in Sediments and Their Associated Risks in the Chenab River, Pakistan. Journal of 
Geochemical Exploration, 165, 62-70. https://doi.org/10.1016/j.gexplo.2016.02.006

[56] Gunnlaugsson, T., Lee, T.C. and Parkesh, R. (2004) Highly Selective Fluorescent Chemosensors for Cadmium in Water. Tetrahedron, 60, 11239-11249. https://doi.org/10.1016/j.tet.2004.08.047

[57] Duarte Zaragoza, V.M., Carrillo, R. and Gutierrez Castorena, C.M. (2011) Lead Sorption-Desorption from Organic Residues. Environmental Technology, 32, 353-361. https://doi.org/10.1080/09593330.2010.491133

[58] Lavecchia, R., Medici, F., Patterer, M.S. and Zuorro, A. (2016) Lead Removal from Water by Adsorption on Spent Coffee Grounds. Chemical Engineering Transactions, 47, 295-300.

[59] Noulas, C., Tziouvalekas, M. and Karyotis, T. (2018) Zinc in Soils, Water and Food Crops. Journal of Trace Elements in Medicine and Biology, 49, 252-260. https://doi.org/10.1016/j.jtemb.2018.02.009 